\section{有機ガラ ス}

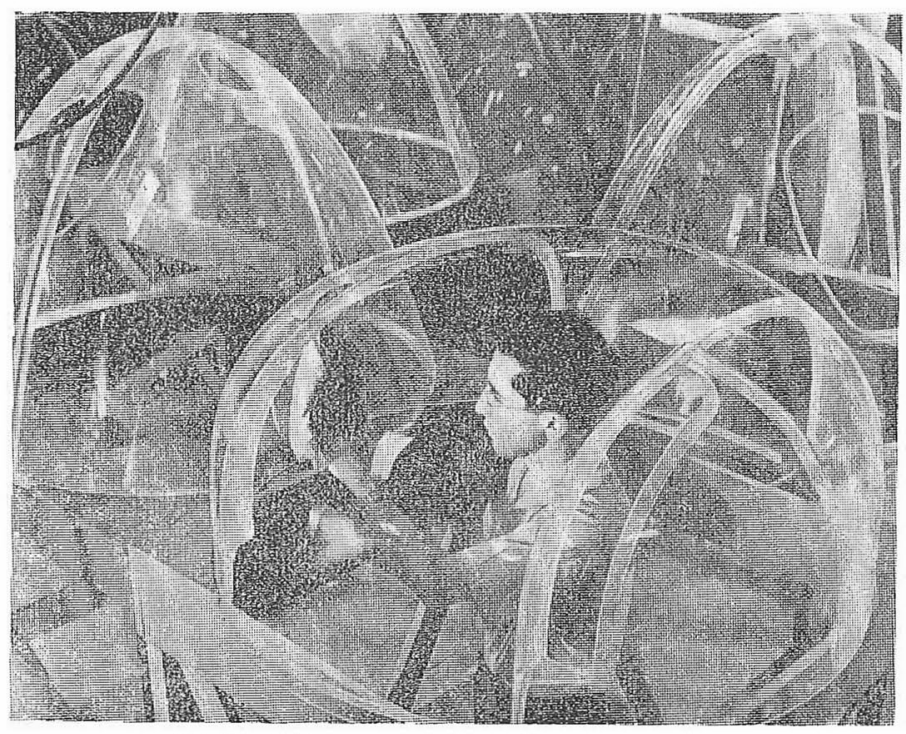

爆撀機䎲使用のプレキシグラス（Röhm u. Haas 社）

る。彼はアクリル酸エステルの長年にわた る研究時代を経て, 1930 年 Röhm u. Haas 社でこの樹脂の用途の 1 つとしての積層安 全ガラスの中間膜として使用しはじめた。 しかしこれがまだ不満足であったため，エ チルメタクリレートとの共重合を用いるこ とに研究を進め, これがメタクリル酸誘導 体の最初の工業的生産に移る導火線となっ た。メチルメタクリレートの工業的生星の 合成法は，これより主として 1933〜1934 年の間に基礎となるいろいるな特許が J. W.C. Crowford (I.C.I.) によってとら れ，工業的基礎が確立した。これは現行法 のアセトンシャンヒドリンを濃硫酸と混合 $し$, 粗製の Methacrylamide sulphate $儿$ 変化し，メタノールと水を反忘せしめてメ タクリル酸メチルを得る方法の工業的生産 の基嘫となった。

またこの合成樹脂の重合注型板は, これ より以前 1930 年ごろより Röhm u. Haas の積層安全ガラスの製法より着想されてい て, 同社永よび米国の du Pont, 英国の I. C. I. で 2 枚のガラス板の間任注型, 剝離 することが研究されていたが，メタクリル 谷山莩次 酸メチルの工業生産が成功するに至って, 1936 年ごろよりこの重合注型板（有機ガ ラス）が市販されはじめたといわれてい る。

わが国のメタクリル樹脂工羓は 比較的新しい工業で, メタクリル樹脂も新しい樹脂であると考えていたが，か えりみると最初われわれの研究室（当時の藤倉工業）で メタクリル樹脂板（有機ガラス）が試作されてからすで に 20 年に近い。近ごろのように進歩の早い有機化学工 業で, 新しい合成樹脂が次々と工業化されてゆく時代に, メタクリル樹脂はもはや新しい合成樹脂といえないかも 知れない。しかしわれわれはこの類のない無色透明さと 化学的な優れた性質をみるたびに，やはり新しい時代の 合成樹脂であるということを信じている。

いまここでわれわれの工場でこのアクリル樹脂板の初 期の研究より生産までに移ったいろいろの失敗と苦心を 述ベることとする。

アクリル樹脂については, 有名な Otto Röhm 氏唯 约 50 年以前 1901 年ごろよりはじまったアクリル酸エ ステルの重合性について注目した。この仕事は, その当 持 Aromatic Chemistry の課題が主流であったドイッ こおいては Aliphatic Chemistry の先駆であったといえ
日本では軍用航空機のため, 当初丸の内にあった高田 商会(株) を通じてドイッのプレキシグラスを軍が輸入し て使用しはじめたが, 国際間の事情が急迫するにつれ, 将 来の航空機として欠くことのできない材料であることを 認め,この国産化を急ぐこととなった。それで昭和 12 年 (1937 年) 藤倉工業は軍用盗材としての生産研究委啒 をらけることとなって大急ぎで研究に着手することとな った。藤倉工業では研究陣容を強化し, 同年中に試作の 域にまでどうにか橧ぎ付け，昭和 13 年にはパイロット の運転をはしめ, 同年 9 月には工場設立（藤化成現工 場）にまで事を運んだという超特急ぶりであった。戦 前, 準戦時体制の時代で今のように外国技術の導入, 文 献の入手が容易でなかった当時としては, 独力で行った この技術追随は非常に早かったといえよう。もっとも工 場建設（昭和 13〜14 年）後の 1 2 年はパイロットプラ ントそのままといってよい状態で生産を強行したので, もらろん採算は成り立たず，基礎研究の不足のためいろ いると苦難と失敗の連続であった。しかし，他面軍需資 
枋としての需要の保証があって，現在のような販売面の 苦学柱くなかったので，当時の低収率でよく持ちこた えられてきたものだと思う。アクリル樹脂工業が戦争の 落し子といわ机る西えんである。

\section{モ/マーの合成}

筆者は当時建設委員であって，もっぱら工場建設担当 者であったので，初期の研究がどのように進められてい ったか，その詳細を知らない。しかし断片的に $2 ， 3$ の 総合をしてみることにする。

仕事をはじめた当初は，中間体のシヤンヒドリンの合 成で注青酸の毒性が強烈であって，これをガス体として 取り扱う経験がないので, 青化ソーダ溶液とアセトンの 混合液中に硫酸を滴下し，反応熱をジャケットの冷凍ブ ラインで泠却することとし，夯スの発生を防止した。こ の初期の反広方式の欠点は, 第 1 亿副生する硫酸ソーダ が器壁に付着して熱伝導を妨げ, 反応の進行するに伴っ て冷却効果が悪くなることで，第 2 亿は水溶液中の反応 であるので，多量の水がアセトンシヤンヒドリンと共存 していて，あとでこれを分離するのに手数がかかって収 率も低く，現行法の上うに高収率は望めなかった。もち ろんこの直後青酸ガスを発生してアセトンに吸収せしめ る方式に改良してからは，この久点はなくなった。

次にアセトンシャンヒドリンと硫酸を混合し，加熱反 応せしめメタクリル酸を得る工程では, この反応条件の 確認が必要であるので実験を行った。それはアセトンシ ヤンヒドリンに硫酸を作用して得られる樹脂状物質を, エーテルで抽出し得られるものを検討した結果, 雨者の 混合物を $100^{\circ} \mathrm{C}$ に加熱すると，その主反応は $\alpha$ オキシ イン酪酸アミドを生じ， $140^{\circ} \mathrm{C}$ に加熱するときにはメタ クリルアミドを生ずることを確認した。その結果この反 応において加熱温度の低、場合, および硫酸濃度の低い 場合は，脱水反応が完全に行われず，aオキシ酪酸メチ ル，またはエステル化不十分のときには $а$ オキシ酪酸 を多量に生成し，エステルの収率を減少せしめる原因と なることが判明した。このように各工程の反応温度およ び硫酸濃度の差異による収率などを検討しつつパイロッ トで生産が行われた。

プラントの初期は耐酸材料の撰定に苦しんだが，いる いろの工業化の条件を加味して鉛以外には処置なく，硫 酸濃度を高めると，この消耗がはなはだしくなって，装 置の補修は全く補給戦のありさまであった。このために 戦時中は多数の鉛工の盖成屯で計画実施した。

精製工程には無色透明のエステルを得るために, 初期 には大いにガラス器具の御厄介になって, 工場内はガラ ス器具林立のありさまで, その滴溜の集積で 1 トン, 2
トンとアクリル樹脂モノマーが生産されていった。

\section{青酸の恐怖}

この仕事の困難さの最も大きい原因は青酸ガス, 青化 ソーダおよび中間体であるアセトンシャンヒドリンの毒: 性にある。研究室より生産に移行する間に最も問題にな ったのはこれであった。

青酸ガスの猛毒性はほとんど通念的のもので，仕事を はじめる前から工場幹部間には 1 つの強迫観念的ですら あった。人を死なせてはならない。まず青酸ガスの毒性 災害䂆防の問題である。ぼの程度で事故を生じるか，ま た作業員にはどの程度知識を与えるか。楽推流禁物であ るが過度の恐怖では仕事にならない。反応装置の密閉, ガス排風機，防毒マスク，ガス検知法と順次に災害対策 が進められていった。

それでも心配であるので, 毎日毎日連日夜間作業の終 了するまで幹部連中は退社することはできない。災害の 発生にそなえて医務室などの救急設備を整光, 夜間, 病 院に災害者を運ぶ自動車を常に待機させた。このような 態勢をととのえてシヤンとドリンのプラントの運転をは じめた。おかげで現在に至るまで工場内で重大な事故者 (ガスを吸って倒机る程度) は極めてわずかであり，救 急法で直ぐ回復し, 工場内で死飞至った者はない。

現在はいろいると経験を経てきて，平気で青化ソーダ を硫酸で分解して青酸ガスとして反応に使用している。 作業員も熟練者で, 処置も適切で, 過度の恐怖威を持た なくなった。が初期はこの反応が恐ろしく, 収率のよく ないことを承知で, 青化ソーダの溶液とアセトンの混合 覮㪵液中に硫酸を滴下するこの液相反応を行った。反応 は比較的安全に反応が行えそうなのでこの安全方策が採 られた。しかしこの反応も発熱反応で, 硫酸の滴下速度 と温度の調節が悪いと, 発熱が急激に行われ, 青酸ガス の発生とともに突沸が生じ青酸や反応液が槽より吹き出 すことがあった。このよらな不慣れなミスのあるときは 災害はなくとも作業員達は恐怖して興畜する。夜退社時 間になると幹部職員室の前に興奮した高声で話して通 る。しかしわれわれはなんとかやらねばならないという 信念のもとに反応装置の新しい図面が引かれ, 反応条件 が研究された。

作業員達は慣れてくると要領がよくなり大胆になる。 この傾向はむしろ装置の修理工の方に多い。装置の解体 は完全洗派後でないと修理に引渡せないしくみになって いるが，作業を急ぐあまり解体をはじめる，このような ときには内にある青酸ガスは上方に上昇するから高所に いる者は伦険である。

あるときは，電気ドリルを使用していた修理工が腹痛 
を訴え悪感を生じた。青酸被害かも知れんと真青になっ た。恶感は止まらない，一刻を争い自動車で病院にかけ つけた。結果は胃腸障害で電気ドリルの振動が，覀威の ふるえを倍加して青酸の被害妄想が生んだ騒ぎに終っ た。しかし青酸による被害の手当は1秒を争う。被害妄 想とばかりいってしま充姡である。

\section{板の製造方式の失敗}

かくしてモノマーが生産されはじめたが，これを透明 の有機ガラス板にする生産方式の決定で，われわれは大 きい誤りを犯した。今にして思觉洗を急ぐのあまり， 重合反応の基礎実験も不十分で，またメタクリルの重合 体が熱可塑性樹脂であることを忘れた計画の誤りであ った。

当時（昭和 13 年）としてはドイッで実際にプレキシ グラスがどのような方式で板にするかは全く不明であ った。それで 2 枚の磨きガラス板の間に注型して重合す る方式と，あらかじめ重合したものをプレス成板する方 法の 2 方法を平行して研究した。

後日文献をみると，Röhm が 積層安全ガラスの製造 方式にメタクリル酸メチルを応用して，その中間膜の永 離することによってメタクリル樹脂の板状製品が得られ たとのことであるが, 彼の注型方式は偶然のことでなく， その仕事の経路よりみて当然のことであった。当然初期 より注型方式を主力にして板の生産を行うべきであっ た。それだけの見通しのなかったわれわれは熱硬化性樹 脂板のプレス方式を真似ることにとらわれ過ぎた。

また一方の注型法の研究も行ったが，いるいるな基礎 実験に欠け，そのテクニックを十分把握していなかった ため，製品は気泡だらけの重合収縮による陥落のあるひ どい板ができ，収率悪く，現在のような大面積の板を確 実に生産することは到底困難であった。当然プレス方式 を採用することとし $1 \mathrm{~m}$ 平方の板のプレスを計画した。 成型圧力 $100 \mathrm{~kg} / \mathrm{cm}^{2}$ としても 1,000 トンの全圧力が必 要で, このため 1,300 トンの大きな油圧成型機と 200 $\mathrm{kg} / \mathrm{cm}^{2}$ の油圧ポンプを数台準備した。また型板として 高価なステンレスの磨き板を各少ズ多数揃えた。板の 製造過程は重合物を機械的纪砕き， 2 枚のステンレス板 の間沃狭えで $180^{\circ} \mathrm{C}$ に加熱加圧し，加圧のまま $40^{\circ} \mathrm{C}$ に 泠却後取出す方式で行った。もらろんこの方式はフェノ ール樹脂のような熱硬化性樹脂では，プレスは泠却の必 要なく、温度を上げたままで能率よく行えたであるらが， この場合は熱可塑性であるため泠却せねばならない。巨 大な重量で熱容量の大きいプレス熱板を繰り返し加熱冷 却することは大へんで, 1 サイクルに数時間を要して 1 台わずか 10 枚程度という情けない状態であった。それ
でも数台のプレスを尽夜兼行で運転し，初期の有機ガラ スを生産した。

そのころ，旭硝子(鶴見工場) でも有機ガラスの生産 がはじめられたが，ガラス製造会社であるだけに初期よ り強化ガラスを使用する注型方式を採用されていたよう である。プレスした板の最大の久点は光学的な表面精度 が研磨したガラス板の注型品より劣ることと，重合物を 機械的に処理するため製品の重合度が低いことであっ た。しかし日本に扮いて有機ガラス板の製造に最も早く 貢献した努力は大、に買わ机た次第である。もちろん， 1 カ年ぐらいで板の生産方式を転換し，プレス方式は廃

国産プレキシガラス試験 （海軍航空政）

\begin{tabular}{|c|c|c|c|}
\hline 研究実験 & $\begin{array}{l}\text { 海軍航空䇘 } \\
\text { 材 料 部 }\end{array}$ & $\begin{array}{l}\text { 研究実験 } \\
\text { 期 }\end{array}$ & \begin{tabular}{|l} 
自昭和 13 年 2 月 20 日 \\
至昭和 13 年 6 月 20 日
\end{tabular} \\
\hline $\begin{array}{l}\text { 研究実験 } \\
\text { 番 }\end{array}$ & 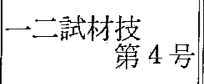 & $\begin{array}{l}\text { 研究実験 } \\
\text { 担 当者 }\end{array}$ & 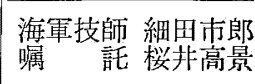 \\
\hline $\begin{array}{l}\text { 訓令通箟 } \\
\text { 等の区分 }\end{array}$ & \begin{tabular}{|l} 
昭和 13 年 2 月 2 日 \\
航本機密 \\
第 751 号照会
\end{tabular} & $\begin{array}{l}\text { 報 告 } \\
\text { 製作者 }\end{array}$ & 実験工手 \\
\hline
\end{tabular}

$$
\text { 第一目的 }
$$

藤倉工業株式会社及旭硝子株式会社提出二係ル国産プレ キシガラス站二当廠試製品二就キ航空用遮風板トシテノ 実用価值 判定スルニアリ

$$
\text { 第二 成果站二所見 }
$$

一、藤倉工業株式会社、旭硝子株式会社及当政試製/国 産プレキシガラス八何レモ同等ニシテ独逸製品卜同 様メタクリル酸メチルラ主成分ト七ル合成樹脂製品 ナリ

二、国産プレキシガラス八成型上不均斎ナル点アルモ最 近参考卜シテ提出セルモノ八厚业均一ニシテ漸次改 良它ラレタリ

三、国産プレキシガラスノ抗張力八独逻製品二比シ劣ル モンノ他ノ諸性質八同等ニシテ航空用遮風板二使用 差支ナキモノト思考スルモ抗張力二関シテハ尚研究 継続ヨ要スルモノト認ム

\begin{tabular}{|c|c|c|c|}
\hline 試 験 項 目 & 藤倉製 & 旭硝子製 & 空廠製 \\
\hline 主 成 分 & \multicolumn{3}{|c|}{ 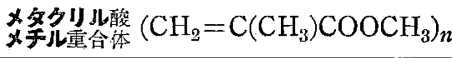 } \\
\hline 重合樹脂分 $(\%)$ & 87.0 & 98.5 & 93.9 \\
\hline エーテル抽出分 $(\%)$ & 13.0 & 1.5 & 6.1 \\
\hline 比重 $\left(15^{\circ} \mathrm{C}\right)$ & 1.183 & 1.185 & 1.180 \\
\hline 硬（度リネル20品) & 16.5 & 17.3 & 17.0 \\
\hline 光線透過率 $(\%)$ & 90 & 88 & 88 \\
\hline 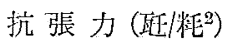 & 3.5 & 4.7 & 4.5 \\
\hline 率 $(\%)$ & 0.5 & 0.3 & 0.3 \\
\hline
\end{tabular}

四、性能比較表

(第 2 ページ以下省略) 

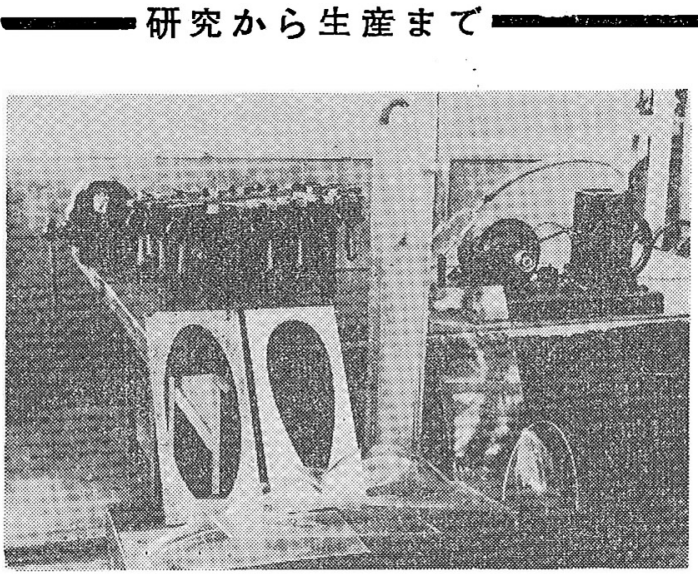

昭和年 17 ごろの真空成型 法の研究装置とその試作品

止して，代って注型方式のみによることにした。しかし 強化ガラスの入手はできず, 普通磨きの板を使用してそ のため重合の際の破損の多いのに閉口した。

歴史は繰返し，現在またアクリル樹脂板の不能率な注 型方式より脱しようとして機械的方式, 押出機による板 の量産方式が実施されようとする時代になってきたのは おもしろいことである。

参考までに当時（昭和 13 年 1 月ごろ）生産されたメ タクリル樹脂板（国産プレキシガラスと称す）の海軍航 空敵に㧍ける試験結果を記載する(前ページ右側)。結果 をみてもプレス方式，キャスチング方式のいずれにして も, 并の抗張力はわずか $3.5 \sim 4.7 \mathrm{~kg} / \mathrm{mm}^{2}$ ぐらいで低 く，初期のものはいかに低重合物であったかがわかる。 その結果をみてわれわれは奮起した。その後, 昭和 14 年 ごろにはすでに抗張力の実験值が 7〜 $8 \mathrm{~kg} / \mathrm{mm}^{2}$ ぐらい に改良され，昭和 16 年の海軍航空規格では規格值が 5 $\mathrm{kg} / \mathrm{mm}^{2}$ に改められた。

昭和 13 年にはまだ有機ガラスの名称はなく, 国産プ レキシガラスと称していた。海軍は有機ガラス，陸軍が 靶性ガラスと名称がはっきり付けられたのは陸; 海, そ れぞれの材料規格がつくられた以後のことである。

\section{加工法の研究}

有機ガラス板が以上のように生産しはじまると直ぐ加 工上の問題が各航空機メーカーで起った。この問題はも ちろん, 板の切断と紫孔からはじまった。その次には風 防としての枠取付縁部の加工と擦り傷の研磨方法が問題 となった。昭和 13 年ごろはまだ日本の爆撃機の風防は 平面の有機ガラスをいろいろと立体的に組み合して使用 されていたが, 急速に航空機も進歩しつつあったので, 速力増加のため曲面風防の成型法の研究も急がねばなら なかった。

われわれの工場では昭和 13 年より旋回機銃々座の半 球型風防を木型で試作したが，その他天蓋風防，翼端照 明燈カバー, 着陸照明灯カバーなど順次曲面加工を行う ようになった。昭和 14 年 10 月には陸軍航空技研で, 陸軍各航空機関, 民間航空会社およびアクリル樹脂メー カーが参加して敬性ガラスの加工を主題とした研究会が 催された。昭和 17 年 9 月には海軍航空技術廠で加工の 研究会があり, 板の曲面成型の問題が論じられ, このと きはすでにアクリル板の気体および液体による膨張成型 法で風防を製作する研究がはじめられていた。

終戦を迎えてすでに 10 年, 今また航空機用ジェット 機としての風防のための材料, 加工法はさらに進歩して いる。この問題についてわれわれの研究はまだまだ限り なく続けなければならない。

(藤化成(株) 取締役技術部長)

\section{会員名簿の作製}

今年末発行を目標に岡副会長を委員長に, 中川鶴太郎, 山崎升, 池田勇一の諸士を委員に打願いして, できるだ け便利で相互裨益するものをつくりたいと努力しており ます。御意見, “御希望のある向きはどしでし係あて御申 出下さい。

\section{摽潰·混合·擋拌·燥り合世を同時にする

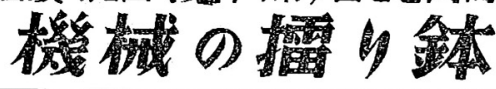

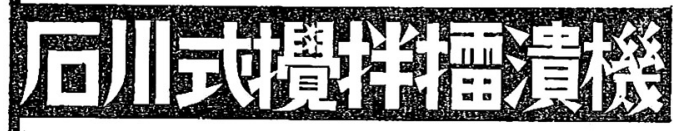

新製品，分析用瑪琌邓はジンターコルンド 磁卷裴乳鉢的棌械発売
替鉣の值径 3 寸位より 4 尺 5 寸位まで 大小加熱用等数百㮔製作

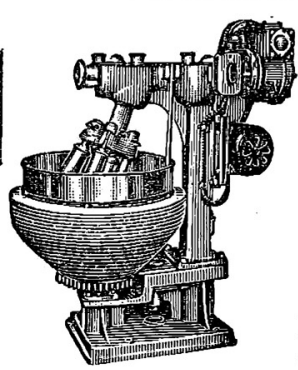

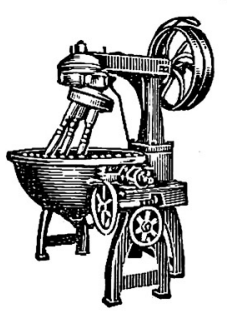

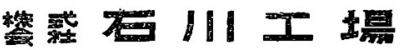
東京都港区芝三田四國町 2 番地 2 号 電話三田(45) 3918 . 8492 